Tropical Journal of Pharmaceutical Research June 2020; 19 (6): 1277-1284

ISSN: $1596-5996$ (print); 1596-9827 (electronic)

(C) Pharmacotherapy Group, Faculty of Pharmacy, University of Benin, Benin City, 300001 Nigeria.

Available online at http://www.tjpr.org

Original Research Article

http://dx.doi.org/10.4314/tjpr.v19i6.24

\title{
Identification, antioxidant and cytotoxic potentials of casticin in Vitex agnus-castus fruit from different geographical regions of Turkey
}

\author{
Gizem Gulsoy Toplan1*, Esra Eroglu Ozkan1, Turgut Taskın², Mahmoud \\ Abudayyak $^{3}$, Afife Mat ${ }^{1}$, Gunay Sarıyar ${ }^{4}$ \\ ${ }^{1}$ Department of Pharmacognosy, Faculty of Pharmacy, Istanbul University, 34116, Beyazit, ${ }^{2}$ Department of Pharmacognosy, \\ Faculty of Pharmacy, Marmara University, 34668, Haydarpasa, Istanbul, ${ }^{3}$ Department of Pharmaceutical Toxicology, Faculty of \\ Pharmacy, Karadeniz Technical University, Trabzon, Turkey, ${ }^{4}$ Faculty of Pharmacy, Cyprus International University, Lefkoşa, \\ Cyprus
}

*For correspondence: Email: eczgizemgulsoy@gmail.com Tel: +902124400000

Sent for review: 10 April 2019

Revised accepted: 16 May 2020

\begin{abstract}
Purpose: To evaluate the antioxidant and cytotoxic effects, and casticin contents of Vitex agnus-castus (VAC) fruit extract from five geographical regions of Turkey.

Methods: Casticin determination in VAC fruit extracts was performed using HPLC-DAD method. The method was validated for linearity, sensitivity, selectivity, accuracy and precision. The methanol extracts of the VAC fruits were analyzed for antioxidant effects using 2,2-diphenyl-1-picrylhydrazyl (DPPH') radical scavenging capacity, metal-chelation capacity assay, radical cation scavenging capacity $\left(A B T S^{++}\right)$, and total phenolic content. The cytotoxic potential of the extracts against NRK-52E and HeLa cells were determined using MTT and LDH assays.

Results: The casticin content of the extracts ranged from 0.048 and $0.152 \%$. Total phenol content was in the range of $36.67 \pm 0.7$ to $74.20 \pm 1.02 \mathrm{mg}$ gallic acid equivalent (GAE)/100 mg of extracts. High-tomoderate antioxidant properties were observed in the extracts. Cytotoxicity data demonstrated that all extracts showed high cytotoxic effects on HeLa cell line when compared to the NRK-52E cell line ( $p<$ 0.05).

Conclusion: These results suggest that VAC fruits (Monk's pepper fruits) from Aegean sea coasts have a potential for use in the preparation of phytopharmaceutical products.
\end{abstract}

Keywords: Vitex agnus-castus, Casticin, Antioxidant, Cytotoxic activity, Anticancer

\begin{abstract}
This is an Open Access article that uses a fund-ing model which does not charge readers or their institutions for access and distributed under the terms of the Creative Commons Attribution License (http://creativecommons.org/licenses/by/4.0) and the Budapest Open Access Initiative (http://www.budapestopenaccessinitiative.org/read), which permit unrestricted use, distribution, and reproduction in any medium, provided the original work is properly credited.
\end{abstract}

Tropical Journal of Pharmaceutical Research is indexed by Science Citation Index (SciSearch), Scopus, International Pharmaceutical Abstract, Chemical Abstracts, Embase, Index Copernicus, EBSCO, African Index Medicus, JournalSeek, Journal Citation Reports/Science Edition, Directory of Open Access Journals (DOAJ), African Journal Online, Bioline International, Open-J-Gate and Pharmacy Abstracts

\section{INTRODUCTION}

Monk's pepper ( $V$. agnus-castus L.) is a plant that grows in the Mediterranean region. The fruits have long been used in traditional medicine for the treatment of gynecological problems all around the world [1]. Currently, the fruit extract of VAC is an approved medication for the treatment of menstrual disorders, premenstrual syndrome (PMS), mastalgia and mastodynie. The beneficial effects of VAC in gynecological treatments have gained the attention of the pharmaceutical 
industry [2,3]. This well-known aromatic shrub grows extensively in coastal areas of Turkey and its fruits are used in Anatolian folk medicine as diuretic, digestive, antifungal, and anxiety medication, and as remedy for stomach ache [4]. Several studies on biological activities of VAC have reported its antioxidant, antimicrobial, antifungal, cytotoxic, and anti-inflammatory properties [5-7].

Previous studies demonstrated that VAC contains flavonoids (casticin), iridoids, diterpenes and essential oil $[5,8,9]$. Casticin is a chemotaxonomic index for the genus Vitex, and also a major phytochemical in VAC fruits. It is a lipophilic flavonoid which has a strong chromophore that makes it easily detectable with UV. Therefore, casticin has been chosen for the standardization of VAC extracts [10]. According to the European Pharmacopoeia of 2007, the dried drug should contain a minimum of $0.08 \%$ casticin [11]. Whether as a food supplement or as medicine, VAC extracts are commercially available and quite popular for the treatment of premenstrual syndrome (PMS), with most of them standardized according to casticin amount [12].

Most of diseases are associated with free radical damage. These include cardiovascular diseases, cancer, autoimmune disorders, and neurodegenerative disease. Medicinal plants have a great potential in the prevention and effective suppression of many diseases. These beneficial effects attract the attention of researchers to study the pharmacological potential of plants. Numerous investigations have been reported on antioxidant and cytotoxic activities of Vitex species $[5,13]$

In this study, quantitative analyses of casticin contents of methanol extracts of five samples of VAC from different coastal areas of Turkey were performed using HPLC-DAD. In addition, the extracts were subjected to in vitro antioxidant and cytotoxic assays by determination of their capacities to scavenge 2,2-diphenyl-1picrylhydrazyl (DPPH•) and 2,2'-azino-bis-3ethylbenzothiazoline-6-sulfonic acid (ABTS•+) radical, and metal-chelation capacity. The total phenolic contents of the extracts were also identified using spectrophotometric techniques.

\section{EXPERIMENTAL}

\section{Chemical agents}

Casticin was purchased from Sigma-Aldrich, Germany. All solutions were of HPLC grade and the compounds used for biological activity were of analytical grade.

\section{Plant material}

The fruits of Monk's pepper were obtained from 5 different coastal areas, namely ManavgatWestern Mediterranean coast (GILAM no: 680), Bodrum-South Aegean Sea (GILAM no: 681), Altınoluk-Mid Aegean Sea (GILAM no: 682), Zonguldak-Western Black Sea coast (GILAM no: 683), Enez-North Aegean Sea (GILAM no: 684) (voucher specimen nos. in brackets). The VAC fruits of were authenticated by Professor Gunay Sariyar and were dried at room temperature (RT) in the dark.

\section{Preparation of extracts}

Five grams of dried and powdered fruit samples were sonicated with $50 \mathrm{~mL}$ of methanol in an ultrasonic bath for $20 \mathrm{~min}$ at RT and filtered. This procedure was repeated twice [11]. The filtrates were pooled and subjected to rotary evaporation at $30{ }^{\circ} \mathrm{C}$, resulting in a residue which was kept at $4^{\circ} \mathrm{C}$ prior to use.

\section{Quantification of casticin in V. agnus-castus samples using HPLC-DAD}

\section{HPLC-DAD conditions}

HPLC analysis was performed on a Shimadzu 10A instrument (SAMI, Japan). The analytical HPLC column (Teknokroma Nucleosil 100 C18 column, $3 \mu \mathrm{m}, 125 \mathrm{~mm} \times 0.3 \mathrm{~mm}$ (TR$\mathrm{N} 1318 \mathrm{C} 12 \mathrm{CL})$ ) was used with gradient mobile phase system. The binary solvent mixture from Solvent A [phosphoric acid: water, 4:996 (v/v)] and solvent B [acetonitril: methanol, 30:70 (v/v)] was used for HPLC analysis.

The mobile phase was used in gradient elution: 0-13 min, $70 \rightarrow 35 \% \mathrm{~A} ; 13-16 \mathrm{~min}, 35 \rightarrow 0 \%$ $\mathrm{A}$; and $16-20 \mathrm{~min}, 0 \rightarrow 70 \% \mathrm{~A}$. at mobile phase speed of $1.5 \mathrm{~mL} / \mathrm{min}$, injection volume of $10 \mu \mathrm{L}$, and column temperature set at $40{ }^{\circ} \mathrm{C}$. Casticin was detected at $348 \mathrm{~nm}$. The procedure was subjected to validation with respect to sensitivity, linearity, selectivity, accuracy and precision according to $\mathrm{ICH}$ provisions [14]. The data analysis procedure was performed with Shimadzu LC Solutions software.

A casticin standard calibration curve was prepared with casticin levels $0.1-0.0625$ $\mathrm{mg} / \mathrm{mL}$. The standard casticin and extracts were disolved in methanol. All samples and solvents were subjected to filtration through $0.45 \mu \mathrm{m}$ 
pores prior to HPLC analyses. All analyses were done in triplicate.

\section{Estimation of phenolics}

Total phenolics were estimated using the procedure described earlier [15]. The total phenolics of each extract was expressed in milligrams of gallic acid equivalent per gram extract (mg GAE/g extract) using a calibration curve with gallic acid (standard solution). The total phenolic content was calculated as shown in Eq 1:

Absorbance $=2.395 x-0.027$ $(1)\left(R^{2}=0.9995\right)$

The absorbance was measured at $760 \mathrm{~nm}$, and the data are presented as mean of triplicate analyses.

\section{DPPH` scavenging effect}

The DPPH • radical scavenging effect of each sample was measured using a method described by $\mathrm{Fu}$ et al. [16]. Serial dilutions were prepared with the stock solution $(5 \mathrm{mg} / \mathrm{mL})$ of each extract. Moreover, $0.1 \mathrm{mM} \mathrm{DPPH} \cdot$ solution in methanol was prepared and $3.9 \mathrm{~mL}$ solution of $\mathrm{DPPH} \bullet$ and $0.1 \mathrm{~mL}$ of different concentrations of each extract were added. After $30 \mathrm{~min}$. in the dark, the absorbance value was measured spectrophotometrically at $517 \mathrm{~nm}$.

\section{$\mathrm{ABTS}^{\bullet+}$ radical cation scavenging activity}

The $\mathrm{ABTS}^{\cdot+}$ radical scavenging activity was assayed according to the method developed by $\mathrm{Re}$ et al [17]. This assay is based on the formation of free radical cation $\mathrm{ABTS}^{\cdot+}$ in a reaction between $A B T S(7 \mathrm{mM})$ and $\mathrm{K}_{2} \mathrm{~S}_{2} \mathrm{O}_{8}$ (2.45 mM), at RT, in the dark, for $12-16 \mathrm{~h}$. In the assay, $3.96 \mathrm{~mL}$ of $\mathrm{ABTS}^{\cdot+}$ solution was made up to $4.00 \mathrm{~mL}$ with extract. After $6 \mathrm{~min}$., optical density of the mixture was measured at $734 \mathrm{~nm}$.

\section{Assay of capacity of extracts to chelate metals}

The metal chelating capacity towards ferrous ions $(\mathrm{Fe} 2+)$ was measured using the procedure of Dinis et al [18]. Samples and EDTA (200 $\mu \mathrm{L})$ were mixed with $2 \mathrm{mM} \mathrm{FeCl}_{2}(50 \mu \mathrm{L})$, followed by addition of $200 \mu \mathrm{L}$ of ferrozine $(5 \mathrm{mM})$ and incubation at RT. Then, the total volume was adjusted to $4 \mathrm{~mL}$ with methanol. The solution remained at $\mathrm{RT}$ for an additional period of 10 min. Finally, the absorbance of the solution was recorded at $562 \mathrm{~nm}$. These assays were done in triplicate for each sample.

\section{Evaluation of cytotoxic activity}

\section{Cell culture and sample treatment}

Rat kidney proximal tubular epithelial cell line (NRK-52E) (CRL-1571 ${ }^{\mathrm{TM}}$ ), and Human cervix adenocarcinoma cell line (Hela) $\left(\mathrm{CCL}-2^{\mathrm{TM}}\right.$, both from ATCC, USA) were used. Rat kidney proximal tubular epithelial cells were maintained on DMEM: nutrient mixture F12 (DMEM/F12), while Human cervix adenocarcinoma cells were maintained on DMEM. The culture media contained $10 \%$ FBS and streptomycin/penicillin mixture (each at $100 \mathrm{U} / \mathrm{mL}$ ). The cells were seeded in 96-well plates at a density of $10^{4}$ cells per well, and incubated at $37{ }^{\circ} \mathrm{C}$ in a $5 \% \mathrm{CO}_{2}$ and $95 \% \mathrm{O}_{2}$ humidified cell incubator for $24 \mathrm{~h}$. The studied concentrations of samples were $0.0125-0.2 \mathrm{mg} / \mathrm{mL}$. After $24 \mathrm{~h}$ of incubation, the toxic effects of the samples assessed with lactate dehydrogenase and MTT assays.

\section{Determination of cytotoxicity with MTT assay}

The methanol extracts of each sample was incubated with cells for $24 \mathrm{~h}$. Then, $30 \mu \mathrm{L}$ of the MTT solution ( $5 \mathrm{mg} / \mathrm{mL}$ in PBS) was applied to each well. The cells with MTT solution were kept in the incubator at $37{ }^{\circ} \mathrm{C}$ for $60 \mathrm{~min}$. Following incubation, the supernatant was removed, and the residue formed was dissolved in DMSO, with shaking for $5 \mathrm{~min}$ at $150 \mathrm{rpm}$ [19]. Thereafter, absorbance of the sample (Abs) and the solvent control (Abso) were measured at $590 \mathrm{~nm}$ against $670 \mathrm{~nm}$, in a microplate reader. The cytotoxicity index $(\mathrm{Cl})$ values were calculated using the formula in Eq 2:

$$
\mathrm{Cl}(\%)=100-\{(\text { Abs } \times 100 /(\text { Abso })\}
$$

\section{Determination of cytotoxicity using $\mathrm{LDH}$ assay}

In present work, Roche Cytotoxicity Detection Kit (Mannheim, Germany) was used to determine cytotoxicity of extracts. After incubating cells with the extracts for $24 \mathrm{~h}$, the culture media were collected separately from cultures and centrifuged to remove cell debris. The assay was conducted immediately by mixing the media with the assay reagent prepared by mixing two separate solutions (diaphorase/NAD+ mixture and iodotetrazolium chloride/sodium lactate mixture) [20]. This was incubated for $0.5 \mathrm{~h}$ in the dark, and optical density was read at $490 \mathrm{~nm}$. Triton-X100 (10\%) was used as positive control for maximum activity. The results were compared with positive control, and $\mathrm{Cl}$ was computed as shown in Eq 3. 
$\mathrm{Cl}(\%)=100-\{($ Abs $\times 100 /($ Abso $)\}$

The $\mathrm{IC}_{50}$ value expresses the concentration of samples that produces a $50 \%$ inhibition of LDH. Negative (untreated, culture medium) and solvent ( $1 \%$ DMSO) controls were used in all assays.

\section{RESULTS}

\section{Extract yields}

The extract yield of VM, VB, VA, VZ and VE samples were 55.3, 88.9, 54.4, 66.8 and 60.4 $\mathrm{mg} / \mathrm{g}$ of dry weight, respectively. Among all the extracts obtained from VAC fruits collected from 5 different locations, the methanol extract of VB had the highest percentage extract yield. The percentage yields of the extracts from VAC are presented in Table 1.

\section{Levels of casticin in V. agnus-castus}

The HPLC method was used for quantification of casticin from fruits of VAC. The identification of the casticin peak was done by comparison of UV spectra of extracts with the UV spectrum of standard casticin. Absorption maxima of casticin standard in methanol was seen at the wavelength of $348 \mathrm{~nm}$. The casticin concentration of extracts was obtained with the regression equation: $y=1 E+07 x+8432.7$, which was linear $\left(r^{2}=0.9991\right)$.

This method was developed to obtain the best resolution. The PDA chromatogram and UV spectra of casticin are given in Figure 1. The association between casticin peak area and concentrations was linear. The levels of casticin in the methanol extracts of samples are presented in Table 1, while LC chromatograms are shown in Figure 2.

\section{Validation}

The HPLC-DAD method was subjected to validation to see if its efficacy was consistent with the appropriate standard for the analysis of casticin from VAC. The HPLC-DAD validation followed the $\mathrm{ICH}$ guidelines "Validation of Analytical Procedures: Text and Methodology Q2(R1)". The results of validation procedure are given in Table 2.

\section{Total phenolic contents}

Table 1 shows that the total phenolic contents of samples varied amongst the extracts. The methanol extract of VM had the largest levels of phenolics (74.20 $\pm 1.02 \mathrm{mg} \mathrm{GAE} / \mathrm{g}$ extract). The order of total phenolic content of the other extracts was VB extract $(60.00 \pm 0.01 \mathrm{mg} \mathrm{GAE} / \mathrm{g}$ extract) > VA extract $(40.67 \pm 0.9 \mathrm{mg} \mathrm{GAE} / \mathrm{g}$ extract) $>$ VZ extract $(40.00 \pm 0.06 \mathrm{mg} \mathrm{GAE} / \mathrm{g}$ extract) $>V E$ extract $(36.67 \pm 0.7 \mathrm{mg} \mathrm{GAE} / \mathrm{g}$ extract).

\section{Antioxidant capacity of extracts}

The results of the antioxidant assays of samples are given in Table 3. The samples showed varying degrees of antioxidant capacity. The $\mathrm{IC}_{50}$ value of positive controls was measured as vitamin $\mathrm{C}\left(\mathrm{IC}_{50}: 0.09 \pm 0.006 \mathrm{mg} / \mathrm{mL}\right)$ and $\mathrm{BHT}$ $\left(\mathrm{IC}_{50}: 0.32 \pm 0.03 \mathrm{mg} / \mathrm{mL}\right)$. The VAC extracts exhibited varying DPPH radical scavenging capacities with VM showing the highest DPPH neutralizing capacity $\left(\mathrm{IC}_{50}: 0.84 \pm 0.02 \mathrm{mg} / \mathrm{mL}\right.$ ). Compared with other samples, methanol extracts of VB (IC $50: 1.25 \pm 0.23 \mathrm{mg} / \mathrm{mL})$ and VZ (IC 50 : $1.74 \pm 0.04 \mathrm{mg} / \mathrm{mL}$ ) showed moderate $\mathrm{DPPH}$ free radical scavenging potential while VA and VE produced poor effects with $\mathrm{IC}_{50}$ values of 2.26 $\pm 0.02 \mathrm{mg} / \mathrm{mL}$ and $2.70 \pm 0.18 \mathrm{mg} / \mathrm{mL}$, respectively.

The ABTS radical cation scavenging activity of $10 \mu \mathrm{g} / \mathrm{mL}$ methanol extracts are presented in Table 3. The VM sample exhibited the strongest ABTS radical neutralizing capacity $(14.95 \pm 0.0$ $\%)$, while the weakest activity was seen in VE sample $(6.33 \pm 0.9 \%)$. The $10 \mu \mathrm{g} / \mathrm{mL}$ extracts of VB, VZ and VA produced $12.87 \pm 0.4 \%, 9.37 \pm$ $0.7 \%, 6.48 \pm 0.6 \%$ inhibition, respectively. None of the extracts was found to be as active as the positive control.

Table 1: Extract yield and total phenolic contents of $V$. agnus-castus fruits

\begin{tabular}{llccc}
\hline $\begin{array}{l}\text { Sample } \\
\text { name }\end{array}$ & Location & $\begin{array}{c}\text { Extract yields } \\
(\mathbf{\%})\end{array}$ & Value of casticin (\%) & $\begin{array}{c}\text { Total phenolics } \\
\text { (mgGAE/g extract) }\end{array}$ \\
\hline VM & Western Mediterranean coast & 55.3 & $0.048 \pm 0.004$ & $74.20 \pm 1.02$ \\
VB & South Aegean Sea coast & 88.9 & $0.152 \pm 0.018$ & $60.00 \pm 0.01$ \\
VE & North Aegean Sea coast & 60.4 & $0.088 \pm 0.009$ & $36.67 \pm 0.7$ \\
VA & Mid Aegean Sea coast & 54.4 & $0.110 \pm 0.003$ & $40.67 \pm 0.9$ \\
VZ & Western Black sea coast & 66.8 & $0.064 \pm 0.003$ & $40.00 \pm 0.06$ \\
\hline \multicolumn{2}{l}{ Data are mean of triple measurements $(\mathrm{n}=3) \pm$ standard deviation; GAE-Gallic acid equivalents }
\end{tabular}


Table 2: Validated parameters for the developed HPLC-DAD method

\begin{tabular}{|c|c|c|c|c|c|c|c|c|c|}
\hline \multirow{2}{*}{ Compound } & \multirow{2}{*}{$\begin{array}{l}\text { Linear range } \\
(\mathrm{mg} / \mathrm{ml})\end{array}$} & \multirow{2}{*}{ Intercept \pm SE ${ }^{a}$} & \multirow{2}{*}{ Slope \pm SE } & \multirow{2}{*}{$\mathbf{r}^{2 b}$} & \multicolumn{2}{|c|}{ Sensitivity } & \multicolumn{2}{|c|}{ Precision $^{\mathrm{e}}$ (RSD\%) } & \multirow{2}{*}{$\underset{(n=6)}{\operatorname{Recovery}{ }^{f}(R \%)}$} \\
\hline & & & & & $\operatorname{LOD}^{c}(\mathrm{mg} / \mathrm{ml})$ & $\mathrm{LOQ}^{\mathrm{d}}(\mathrm{mg} / \mathrm{ml})$ & $\begin{array}{c}\text { Intraday } \\
(n=6)\end{array}$ & $\begin{array}{c}\text { Interday } \\
(n=9)\end{array}$ & \\
\hline Casticin & $0.00625-0.1$ & $4.61 \mathrm{E}+03 \pm 1.35 \mathrm{E}+04$ & $1.27 \mathrm{E}+07 \pm 5.37 \mathrm{E}+06$ & 0.9992 & $0.0083 \pm 0.01$ & $0.0252 \pm 0.03$ & 2.6 & 8.9 & $96.0-112.0$ \\
\hline
\end{tabular}

a: Standard error, b: Coefficients of correlation, c: Limit of detection, the lowest analyte concentration that produces a response detectable above the noise level of the system, $\mathrm{d}$ : Limit of quantification, the lowest level of analyte that can be accurately and precisely measured, e: Relative standard deviation, expressed as \%, f: Average of recoveries at two spike levels $(0.1-0.05 \mathrm{mg} / \mathrm{ml})$
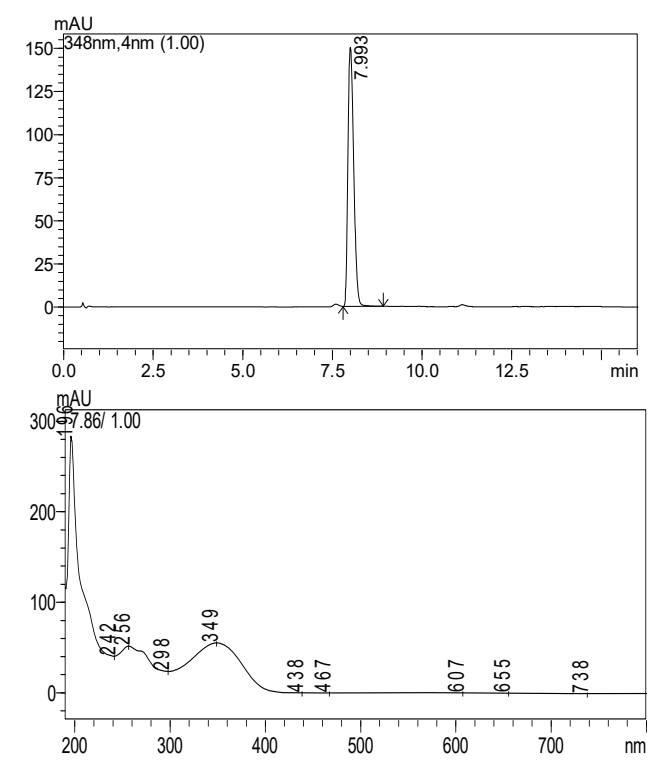

Figure 1: PDA chromatogram (a) and UV spectrum (b) of casticin standard
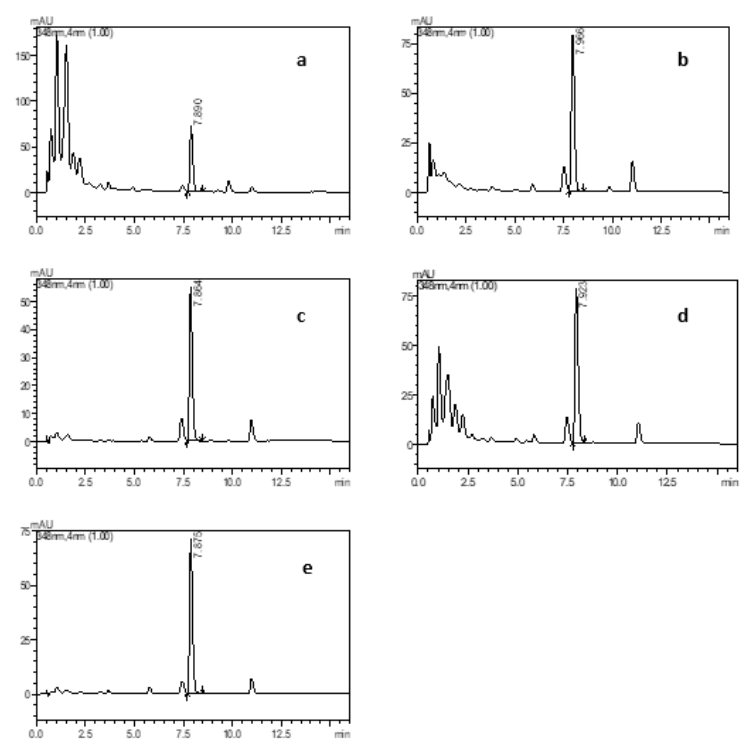

Figure 2: LC chromatogram of the samples (A: Manavgat, B: Bodrum, C: Altınoluk, $\mathrm{D}$ : Zonguldak, E: Enez) 
Toplan et al

Table 3: Antioxidant capacities of V.agnus-castus fruits, which were collected from five different regions

\begin{tabular}{|c|c|c|c|}
\hline Extracts/standard & DPPH (IC $\left.{ }_{50}: \mathrm{mg} / \mathrm{mL}\right)$ & ABTS (\%) $(10 \mu \mathrm{g} / \mathrm{mL})$ & $\begin{array}{l}\text { Metal chelating activity } \\
(\%)(50 \mu \mathrm{g} / \mathrm{mL})\end{array}$ \\
\hline VM & $0.84 \pm 0.02^{a}$ & $14.95 \pm 0.03^{a}$ & $17.50 \pm 0.8^{\mathrm{a}}$ \\
\hline VB & $1.25 \pm 0.23^{b}$ & $12.87 \pm 0.4^{b}$ & $8.53 \pm 0.6^{b}$ \\
\hline VE & $2.70 \pm 0.18^{c}$ & $6.33 \pm 0.9^{c}$ & $5.91 \pm 0,03^{c}$ \\
\hline VA & $2.26 \pm 0.02^{d, c}$ & $6.48 \pm 0.6^{\mathrm{d}, \mathrm{c}}$ & $14.35 \pm 0.6^{d}$ \\
\hline VZ & $1.74 \pm 0.04^{\mathrm{e}}$ & $9.37 \pm 0.7^{e}$ & $13.87 \pm 0.5^{e, d}$ \\
\hline Ascorbic acid & $0.09 \pm 0.006^{f}$ & - & - \\
\hline $\mathrm{BHT}$ & $0.32 \pm 0.03^{g}$ & $54.39 \pm 0.1^{f}$ & - \\
\hline EDTA & - & - & $96.51 \pm 0.2^{f}$ \\
\hline
\end{tabular}

Table 4: IC 50 values of the extracts of the $V$. agnus-castus samples and casticin in HeLa and NRK-52E cell line

\begin{tabular}{ccccc}
\hline & \multicolumn{2}{c}{ LDH $(\mathbf{m g} / \mathbf{m l})$} & \multicolumn{2}{c}{ MTT $(\mathbf{m g} / \mathbf{m l})$} \\
\cline { 2 - 5 } Sample & HeLa & NRK-52E & HeLa & NRK-52E \\
\hline VM & 0,057 & 0,044 & 0,096 & 0,038 \\
VB & 0,004 & 0,083 & 0,036 & 0,137 \\
VE & 0,033 & 0,027 & 0,035 & 0,023 \\
VA & 0,022 & 0,018 & 0,030 & 0,029 \\
VZ & 0,029 & 0,059 & 0,063 & 0,060 \\
Casticin & $0,0062 \mathrm{ug} / \mathrm{ml}$ & $0,0297 \mathrm{ug} / \mathrm{mL}$ & $0,01 \mathrm{ug} / \mathrm{mL}$ & $0,034 \mathrm{ug} / \mathrm{mL}$ \\
\hline
\end{tabular}

Table 3 show results of $\mathrm{Fe}^{2+}$ chelating ability of the samples and EDTA. None of the extracts exhibited strong ferrous ion chelating activity. Among the studied extracts, VM samples exhibited the highest metal chelating activity which was lower than the metal chelating activity of the positive control. The hierarchy of metal chelating activity of the methanol extracts was VM $(17.50 \pm 0.8 \%)>\operatorname{VA}(14.35 \pm 0.6 \%)>V Z$ $(13.87 \pm 0.5 \%)>\operatorname{VB}(8.53 \pm 0.6 \%)>\operatorname{VE}(5.91 \pm$ $0.03 \%)$.

\section{Cytotoxic activity of extracts}

The results of cytotoxic potential of VAC extracts against the two cell lines, as determined with MTT and LDH assays are summarized in Table 4.

The $\mathrm{IC}_{50}$ value of the casticin against HeLa cell line was $0.01 \mathrm{ug} / \mathrm{mL}$ in MTT assay, while its $\mathrm{IC}_{50}$ value determined as $0.006 \mu \mathrm{g} / \mathrm{mL}$ with $\mathrm{LDH}$ assay.

\section{DISCUSSION}

In the present study, the concentration of casticin in the methanol extracts were determined by HPLC-DAD. During the HPLC-DAD analysis, one unknown compound detected in a small amount interfered with the casticin peak. Based on its retention time and UV spectra, this compound was identified as penduletin, which is another lipophilic flavonoid found in small quantities in the fruit extract. The developed HPLC-DAD method provides high resolution between casticin and penduletin. Casticin is employed for standardisation of VAC preparations [10]. Due to its significance in pharmaceutical industries, quantitative analysis of casticin was determined in the methanol extracts of VAC fruits from five different parts of Turkey. These regions are different coastal areas of Turkey with variabilities in climate and geographic conditions. It is well known that chemical composition and quantities of some compounds of plants can be affected by their growth conditions.

The amounts of casticin in the methanol extracts from VAC samples (VM, VB, VB, VZ and VE) were $0.048,0.152,0.110,0.064$ and $0.088 \%$, respectively. When the samples were compared with each other, VB was found to have the highest percentage of casticin. The quantity of casticin in the sample of VA was very similar to that of sample from VB, and both samples were taken from an area near the Aegean Sea. Previous studies on the fruits of VAC showed casticin levels ranging from 0.025 to $0.212 \%$ [21]. The results from the present study showed that samples from VB, VA and VE contained more than $0.08 \%$ of casticin, while samples from VM and VZ contained low amounts of casticin. From the validation results, the developed HPLC method achieved acceptable linearity, sensitivity, selectivity, accuracy as well as precision during the simultaneous analysis of casticin in the methanol extracts. 
In recent years, investigation on natural antioxidants has increased considerably. There are several reports on antioxidant properties of VAC. According to previous studies, VAC extracts showed remarkable antioxidant activity $[13,22]$. In the present study, the methanol extract of VM which had the highest amount of phenolics, manifested the best radical scavenging and metal-chelating capacities. As is well known from the literature, phenolic contents contribute to strong antioxidant capacity. These results indicate a high correlation between total phenolic contents and antioxidant activity (metal chelating, DPPH and ABTS assays) of the methanol extracts VM and VE. However, total phenolic level was not correlated with and antioxidant potential (metal chelating, DPPH and ABTS assays) in the methanol extracts $V B, V Z$ and VA. These results show that VM samples exhibited a significant antioxidant activity. Further studies are needed to investigate fruits from Western Mediterranean coast of Turkey. Many studies have been done on cytotoxic activity of VAC extracts and their major compounds [7,2325]. Several studies have demonstrated that the extracts of VAC showed remarkable cytotoxic activity against various human cancer cell lines [23-25]. In this study, besides the extracts, the effect of casticin was also investigated on NRK and HeLa cells. Casticin, as a major component of VAC, has been researched on for anticancer activity against different types of cell lines $[23,24]$. Furthermore, significant cytotoxic effect was observed for all extracts and casticin against HeLa cell line, but the effect against NRK cell line was weak in all tests. From the MTT and LDH results, the extract of $V B$ exhibited the highest cytotoxic activity against HeLa cells but this extract had no cytotoxic effect against NRK-52E cells at the concentration of, or below 0.083 $\mathrm{mg} / \mathrm{mL}$. Consequently, the high level of casticin may be responsible for cytotoxic effect of VB extract. On the other hand, in the other extracts, there was no correlation between cytototoxic activity and percentage of casticin. As a result, all methanol extracts exhibited considerable cytotoxic activity against HeLa cell lines.

\section{CONCLUSION}

This is the first report on casticin contents of Turkish samples of VAC fruits and their cytotoxic and antioxidant potential, and is a significant contribution to the body of existing knowledge, especially that VA and VB extracts contain high concentrations of casticin compatible that meets European Pharmacopoeia standards. Thus, these fruits can be used in the pharmaceutical industry for the preparation of VAC drugs.
However, the cytotoxicity observed in the VB extract requires further studies.

\section{DECLARATIONS}

\section{Conflict of interest}

No conflict of interest is associated with this work.

\section{Contribution of authors}

We declare that this work was done by the author(s) named in this article and all liabilities pertaining to claims relating to the content of this article will be borne by the authors. The study was designed by Gizem Gülsoy Toplan and Gunay Sariyar. Gizem Gülsoy Toplan, Esra Eroglu Ozkan, Turgut Taskın and Mahmoud Abudayyak collected and analysed the data. The manuscript was written by Gizem Gülsoy Toplan and Afife Mat. All authors have read and approved the manuscript for publication.

\section{Open Access}

This is an Open Access article that uses a funding model which does not charge readers or their institutions for access and distributed under the terms of the Creative Commons Attribution License (http://creativecommons.org/licenses/by/ 4.0) and the Budapest Open Access Initiative (http://www.budapestopenaccessinitiative.org/rea d), which permit unrestricted use, distribution, and reproduction in any medium, provided the original work is properly credited.

\section{REFERENCES}

1. Padmalatha K, Jayaram K, Raju NL, Prasad MNV, Arora $R$. Ethnopharmacological and biotechnological significance of Vitex. Biorem Biodiv Bioavail 2009; 3:614.

2. Schellenberg R, Zimmermann C, Drewe J, Hoexter G, Zahner C. Dose-dependent efficacy of the Vitex agnus castus extract Ze 440 in patients suffering from premenstrual syndrome. Phytomedicine 2012; 19:13251331.

3. Meena AK, Singh $U$, Yadav AK, Singh B, Rao MM. Pharmacological and Phytochemical Evidences for the Extracts from Plants of the Genus Vitex - A Review. Int J Pharm Clin Res 2010; 2:1-9.

4. Baytop T. Türkiye de Bitkilerle Tedavi. Istanbul: Nobel Tıp Kitabevleri; 1999. 480 p.

5. Barnes J, Anderson LA, Phillipson DJ. Herbal medicines: a guide for healthcare professionals. 3th ed. Pharmaceutical Press; 2003. 721p. 
6. Saglam H, Pabuçcuo A, Kıvçak B. Antioxidant Activity of Vitex agnus-castus L. Extracts. Phytother Res 2007; 2:1059-1060.

7. Duymuş HG, Çifţ̧i GA, Yıldırım ŞU, Demirci B, Kırımer $N$. The cytotoxic activity of Vitex agnus castus $L$. essential oils and their biochemical mechanisms. Ind Crop Prod 2014; 55:33-42.

8. Kırmızıbekmez H, Demir D. Iridoid Glycosides and Phenolic Compounds from the Flowers of Vitex agnuscastus. Helv Chim Acta 2016; 1212:518-522.

9. Kuruüzüm-Uz A, Ströch K, Demirezer LÖ, Zeeck $A$. Glucosides from Vitex agnus-castus. Phytochemistry 2003;63(Pt 8):959-964.

10. Hoberg E, Meier B, Sticher O. Quantitative highperformance liquid chromatographic analysis of casticin in the fruits of Vitex agnus-castus. Pharm Biol 2001; 39:57-61.

11. European Pharmacopoeia. Herbal Monographs, Agnus Castus Fruit (Agni casti fructus). 6th ed. 2007. p. 1116 1117.

12. Mari A, Montoro P, Pizza C, Piacente S. Liquid chromatography tandem mass spectrometry determination of chemical markers and principal component analysis of Vitex agnus-castus $L$. fruits (Verbenaceae) and derived food supplements. J Pharm Biomed Anal 2012; 70:224-230.

13. Gökbulut A, Özhan O, Karacaoğlu M, Şarer E. Radical Scavenging Activity and Vitexin Content of Vitex agnuscastus Leaves and Fruits. FABAD 2010; 35:85-91.

14. Branch SK. Guidelines from the international conference on harmonisation (ICH). J Pharm Biomed Anal 2005; 38:798-805.

15. Slinkard K, Singleton VL. Total phenol analysis: automation and comparison with manual methods. Am J Enol Vitic 1977; 28:49-55.

16. Fu W, Chen J, Cai Y, Lei Y, Chen L, Pei L, Zhou D, Liang $X$, Ruan J. Antioxidant, free radical scavenging, antiinflammatory and hepatoprotective potential of the extract from Parathelypteris nipponica (Franch. et Sav.) Ching. J Ethnopharmacol 2010; 3:521-528.

17. Re R, Pellegrini N, Proteggente A, Pannala A, Yang M, Rice-Evans $C$. Antioxidant activity applying an improved
ABTS radical cation decolorization assay. Free Radic Biol Med 1999; 26:1231-1237.

18. Dinis TCP, Madeira VMC, Almeida LM. Action of phenolic derivatives (acetaminophen, salicylate, and 5aminosalicylate) as inhibitors of membrane lipid peroxidation and as peroxyl radical scavengers. Arch Biochem Biophys 1994; 315:161-169.

19. Alley MC, Scudiero DA, Monks A, Hursey ML, Czerwinski $M J$, Fine $D L$, Abbott BJ, Mayo JG, Shoemaker RH, Boyd MR. Feasibility of drug screening with panels of human tumor cell lines using a microculture tetrazolium assay. Cancer Res 1988; 48:589-601.

20. Legrand C, Bour JM, Jacob C, Capiaumont J, Martial A, Marc A, Wudtke M, Kretzmer G, Demangel C, Duval D. Lactate dehydrogenase $(\mathrm{LDH})$ activity of the number of dead cells in the medium of cultured eukaryotic cells as marker. J Biotechnol 1992; 25:231-243.

21. Hoberg E, Meier B, Sticher O. Quantitative HighPerformance Liquid Chromatographic Analysis of Casticin in the Fruits of Vitex agnus-castus Quantitative High-Performance Liquid Chromatographic Analysis of Casticin in the Fruits of Vitex agnus-castus. Phytochem Analysis 2000; 11:327-329.

22. Sarikurkcu C, Arisoy K, Tepe B, Cakir A, Abali G, Mete E. Studies on the antioxidant activity of essential oil and different solvent extracts of Vitex agnus castus $L$. fruits from Turkey. Food Chem. Toxicol 2009; 47:2479-2483.

23. Chen D, Cao J, Tian L, Liu F, Sheng X. Induction of apoptosis by casticin in cervical cancer cells through reactive oxygen species-mediated mitochondrial signaling pathways. Oncol. Rep 2011; 26:1287.

24. Tang SY, Zhong MZ, Yuan GY, Hou SP, Yin LL, Jiang $H$, Yu ZY. Casticin, a flavonoid, potentiates TRAIL-induced apoptosis through modulation of anti-apoptotic proteins and death receptor 5 in colon cancer cells. Oncol Rep 2013; 29:474-480.

25. Yang $F$, He K, Huang L, Zhang L, Liu A, Zhang J. Casticin inhibits the activity of transcription factor Sp1 and the methylation of RECK in MGC803 gastric cancer cells. Exp Ther Med 2017; 13:745-750. 